\title{
The use of Napier Bones props to enhance learning achievement on Grade 5 Math multiplication
}

\author{
Tri Yuriana \& Suwardi
}

SDIT Assalam Bandungan

IAIN Salatiga

triyuriana28@gmail.com

DOI: 10.18326/mudarrisa.v10i2.188-205

\begin{abstract}
The research aims to find out the improvement of students achievement in the subject of Mathematics on the aspect of multiplication by using the teaching aid of Napier Bones. This research is conducted on the frame of class action research upon two cycles. The context of the research is at Islamic Elementary School (MI) Ma'arif Dukuh, Salatiga. The population covers 21 of fourth grade students. The method of data population includes documentation, observation, and test. Meanwhile, the data analysis uses percentage formula. This research find out that the teaching aid of Napier Bones improve students achievement on the subject of Mathematics upon the research subjects. The significant of the result can be overviewed from the $85.71 \%$ of students that have achieved the standard of minimum completeness. It means that the teaching aid of Napier Bones is significantly proven to improve learning achievement on the aspect of multiplication.
\end{abstract}

Keywords: science props, Napier Bones, Islamic Elementary School, classroom action research 


\section{Mudarrisa: Jurnal Kajian Pendidikan Islam, Vol. 10, No. 2, 2018}

\section{INTRODUCTION}

The field of Mathematics study is one of important subjects as the basis of science knowledge. The implementation of Mathematics applies in all levels of education starting from elementary to tertiary. Based on the regulation of the Ministry of National Education No 2 Year 2011 on the procedure of Standard Operation of National Examination, it explicates that Mathematics is one of the main subjects to pass the National Examination.

Mathematics is a symbolic language that possesses practical functions to express the interconnection of quantitative and space that require intelligent emotional capabilities (Adina \& Colomeischi, 2015:748). Learning Mathematics can be seen as teaching and learning process designed by teachers to develop students thinking creativity and to improve new knowledge construction ability as an effort to develop the mastery of Mathematics (Susanto, 2013:186-187).

The objectives of learning in Elementary school/MI are to understand the basic concepts of Mathematics, use of thinking logic, formulate model solution in Mathematics learning materials, communicate ideas in formulation solution in learning Mathematics, and considerate the use of Mathematics in daily life (Susanto, 2013:190). For those purposes, there is formulation that the scope of Mathematics standard materials at the level of Elementary school / MI covers numerals, geometry and measurement, and data analysis. 


\section{Mudarrisa: Jurnal Kajian Pendidikan Islam, Vol. 10, No. 2, 2018}

Mathematics owns well defined languages and rules, clear and systematic reasoning, and structures or robust interconnection among the concepts. The main aspect of Mathematic work is to have deductive reasoning that produces upon basic assumptions (truth consistence). Besides, Mathematics proceeds through deductive reasoning based on raising facts and phenomena to meet a certain prediction. However, the prediction should be proven deductively with consistent arguments.

Commonly, learning Mathematics assumes as a difficult subject for students at the education level of elementary and tertiary. The issue is supported by Daryanto (2013: 155) that Mathematics grade of National Examination is at the bottom. This low grade is disadvantage because Mathematics subject is the basic knowledge for other knowledge.

This subject becomes unpopular subject for students. It is difficult to understand the subject at the levels of Elementary schools/MI, secondary or even tertiary schools. The fierce of Mathematics is another issue compared to other learning subjects, and students have such experience as they have found Mathematics since learning at Elementary School/MI or even Kindergarten (Daryanto, 2013: 155).

The materials of multiplication in Mathematics for Elementary School/MI assume as a difficult case to understand. This concept means equivalent to multiplied addition. The understanding of addition concept becomes an important aspect for students before learning multiplication. Therefore, the case of multiplication becomes difficult materials for them. Such issues can be preview from the number of elementary/MI students 
that have not mastered the concept of multiplication, so they found themselves difficult to learn further materials of Mathematics. The use of teaching aids is in the hope of assisting students to learn the concept of multiplication. Literally, multiplication is multiplied addition, and it is symbolised with "X".

Mathematics is assumed as a difficult subject, but students need to study it as the mean to solve daily basis cases and as the basic learning subject (Sundayana, 2015: 2). The use of Mathematic in solving everyday cases is on the use of information, the knowledge of share and size, computation, finding the connection among several things.

The abstract object of Mathematics is one issue confronted by students in their learning (Marti, 2015: 3). Students and teachers find Mathematics difficult due to the abstract characteristic. If it is concrete, Mathematics will be easy to understand.

The performance indicator of learning process can be seen from students learning outcome. Students' achievement is the ability gained from learning process, so it will create relatively constant changes (Susanto, 2013: 5). In the activity of learning or instruction, teachers define the learning objectives for students. The successful students are the ones that achieve those objectives or instructional goals.

In learning Mathematics, teachers often find difficulties in presenting teaching materials. Mathematics teachers in conducting class interactions at school have limitation in explaining concrete descriptions of presented materials, so it will create the imbalance learning outcome of 


\section{Mudarrisa: Jurnal Kajian Pendidikan Islam, Vol. 10, No. 2, 2018}

each student. The condition occurs perpetually when Mathematics teachers posit themselves as the learning sources for students and ignore the roles of media and teaching aids in learning.

Media and teaching aids can be occupied to cope with the difficulties of Mathematics teachers in conducting teaching. Media can affect to students attitude and behaviours. Therefore, media becomes the bridge to dispense learning information or message transmitter. In fact, media can be in form of human, materials, or occurrence that constructs condition for students to gain knowledge, skills, or attitude (Gerlach and Ely, 1971: 36; Suwardi, 2017: 3). In this sense, teachers, text books, and school environment are part of media (Sundayana 2015: 4). Meanwhile, Gagne and Briggs in Arsyad (2009: 4) explicitly say that learning media include tools for physical use to present learning materials such as books, tape recorder, cassette, video camera, video recorder, film, slides (framed pictures), photo, pictures, graphics, televisions, and computers. In short, media are learning source components or physical media containing instructional materials in students surrounding that stimulate students to learn.

The cognitive development of children is affected by the environment condition, experience, and background information (Suwardi, 2017: 220). This fact shows that material presentations through media or teaching aids will affect to the cognitive aspect of learning outcome. In teaching and learning process, two important aspects relate to teaching methods and related teaching media. The selection of certain 


\section{Mudarrisa: Jurnal Kajian Pendidikan Islam, Vol. 10, No. 2, 2018}

teaching methods will follow the selection of teaching media although there are several other aspects to be considered out of methods such as learning objectives, assignments and expected responses from students after the teaching, and learning context including student's characteristics. Regardless that argument, it simply says that one of media main functions in learning is as teaching aids to affect nuance, condition, and learning environment designed and created by teachers.

According to Livie and Lentz in Sundayana (2015), they mention four functions of learning media on visual media such as attention, effectiveness, cognitive, and compensatory. Learning media can improve interest, motivation, stimulation, and psychology toward students (Arsyad, 2009: 15). The use of learning media in teaching Mathematics in the orientation stage can improve interest, effectiveness, and ignite students' motivation. Thus, Mathematics teachers can occupy appropriate media or teaching aids to the topic discussions.

Interesting and innovative learning media surely invite students' interest to study, so they will have higher achievement. The process of learning mainly has four components including learning materials, learning circumstance, media, and learning resources also teachers as the subjects of learning (Mujiono, 2015: 25).

In the activities of teaching and learning, the use of term of media is replaceable with other terms such as auditory visual tools, instructional material, audio-visual communication, the education of visual tools, technology, teaching aids, and presentation tools (Rambousek et al., 
2016). Teaching aids on the basis of spacious concepts explicate the landmass, the expanse of surface, algebra multiplication, and degree of angle. The example of such aid is tartan board used to define the bandwidth of irregular and regular geometry shapes.

In another case, teaching aids on the basis of length concept provide description of arithmetic operation namely addition, subtraction, multiplication, and division. The types of teaching aids for the concepts of length constancy including numeral scales, sliding rulers, and sticks of Cuissenaire. Numeral scales use to calculate arithmetic operation of addition, subtraction, multiplication, and division. Meanwhile, sliding ruler is intended to addition of integer and it can be produced by using carton papers. The stick of Cuisenaire becomes a teaching aid to help students in understanding Mathematics concepts on addition, subtraction, multiplication, and division of integer (Ningsih and Purwanto, 2015: 1912).

Teaching aids on the basis of volume concept are used to display the concepts of geometry volume. By so doing, students can calculate the geometry volume such as cube, block, prism, tube, pyramid, cone, and spherical objects. Teaching aids on the basis of measurement include metre wheels to calculate range, spirometer and ball clamp used to measure ball-spokes, sliding compasses to measure object thickness, and klinometer to measure object height.

Teaching aids on the basis of arithmetic concepts cover stones, abacus, and sliding ruler to calculate addition and subtraction; Napier 
bone to solve the exercise of multiplication; arithmetic funnel and Dakon to find out the value of Least common multiple (KPK) and Greatest common divisor (FPB); and talipas, smart lamp, and multiplication tube to resolve arithmetic questions.

Teaching aids on the basis of geometric concepts are used to help students learning geometric materials. The samples of these aids are namely tiling, nail board, plane mirror, pantograph, and domino card. Tiling is used to define the composition pattern on the topics of geometric models. Nail board is occupied as a teaching aid in order to understand the concept two dimensional figures. Plane mirror is used to instil the concept of reflection and mirroring of a focus through laboratorial practicum. Pantograf is an aid to zoom in and out of pictures. Meanwhile, domino card is used to exercise memory and understanding about formulas of capacious of two dimensional figures, the expanse of surface, and volume of space. Teaching aids on the basis of probability theories is used to conduct experiments on opportunity / empirical probability. The shape of teaching aids on the basis of theories can be in form of money, dice, spinning gasing, bridge card, or boxes with colourful marbles.

Teaching aids on the basis of gaming can be used to teach Mathematics in the frame of playing games. The sample of this aid is Mathematics domino coined as domat. The domat is like casual domino card, but such card contains varieties of questions and answers. Instead of that, jumping frog also belongs to this type of teaching aids. It is applied to 


\section{Mudarrisa: Jurnal Kajian Pendidikan Islam, Vol. 10, No. 2, 2018}

define the numeral patterns of number line and find out part to $n$ line patterns of number by having exploration.

According to Rusfendi in Sundayana (2015), there are requirements to be teaching aids and media including durability, inviting shapes and colours, simple and manageable, appropriate sizing, presenting Mathematics concepts in the forms of realia, pictures, or diagram, explaining Mathematics concepts not in reverse, as the basis of development of abstract thinking concept for students, encouraging students to think actively and independently by manipulating the aids or media, if possible the media have more advantages.

In teaching Mathematics, the teaching aid of Napier can be occupied. Napier bone or Napier stick is a calculation tool firstly introduced by John Napier, an expert of Mathematics found logarithm, and he has create this tool specifically to calculate of multiplication. At the first place, the tool is intended to multiply in decimal system (ten basis) (Sundayana, 2015: 110). Its name is originally taken from the inventor, John Napier born in Merchiston castle year 1550. John Napier is a mathematician in the sixteenth century developing logarithm from bones or chips. In his book, entitled Rabdologiae, Napier explains how to calculate by moving the chips on the chest board, and then they are named as Napier bones. These bones consist of ten cards as the decimal includes 10 number from $0,1,3,4,5,6,7,8$, and 9 . Those ten cards are the cards with $0,1,2,3,4,5,6,7,8$, and 9 (Sundayana, 2015: 110). 
MI Ma'arif Dukuh is a private Islamic elementary school in Salatiga. Similar with the other MI, it applies the school based curriculum (KTSP). Based on an interview with Mathematics teachers of fourth grade, there are several hindrances in presenting Mathematics teaching. The main obstacle is about students' enthusiasm in learning.

Based on that information, the observation is conducted at MI Ma'arif Dukuh in 26 September 2016, and the result states that during the process of learning, the students seem to be not enthusiastic in following the learning. It can be seen from their multi-tasking activities such as chatting and teasing their friends while they are amid the learning process. In this situation, the teacher does not use any media or teaching aids. As the consequence, the Mathematics achievement of fourth grade is categorized into low level. It can be seen from minimum completeness criteria (KKM) for Mathematics at 65. From the interview with the Mathematics teacher of fourth grade MI Ma'arif Dukuh, there is information that the students often find themselves difficult to answer the exercises, and they do not give full attention during the teaching and learning process. The researcher and the teacher presume that the learning does not invite students' attention because it does not occupy media or teaching aids. Thus, it causes the lower achievement of Mathematics at fourth grade students of MI Ma'arif Dukuh Salatiga.

To cope with such situation, the researcher with the teacher try to conduct an alternative effort by using the teaching aid of Napier bones in teaching Mathematics on the aspect of multiplication. This aid of Napier 
bones is a tool to help students find the result of number multiplication. Napier bones itself is innovated by mathematician that found logarithm, John Napier (Sundayana, 2015: 110). The use of this aid is in the hope of creating an interesting teaching and learning, so students' achievement will increase.

In the article written by Sri Wulan Anggraeni in the journal volume 2 No 1 September 2017, she concludes that the use of table media of Napier bones has improved students' learning outcome. The research also applies the method of class action research with two cycles. In this research, the use of such media has been capable to overcome students' difficulties in answering the exercises of multiplication operation. The research is conducted by showing the table of Napier bones without exhibiting the real teaching aid of Napier bones. Meanwhile, this research is preceded the teaching and learning process by showing the teaching aid of Napier bones and explain how to use it. By presenting the real tool in front of the class, students surely will have more interest and enjoy the class because they can practice to use it by moving those bones.

\section{METHODS}

The approach of this research occupies quantitative method. In this sense, the researcher applies class action research into two cycles. Each cycle undergoes four stages including planning, acting, observing, and reflecting. The research context is in MI Ma'arif Dukuh, Salatiga. The population involves 21 students of fourth grade, and the method of data population is 
by incorporating documentation, observation, and test. Finally, the data analysis uses percentage analysis.

\section{RESULTS AND DISCUSSIONS}

The previous Mathematics teaching and learning in MI Ma,arif Dukuh before the research never uses any media or teaching aids. Therefore, students' understanding toward Mathematics materials is poor. It is mainly caused by the abstract learning materials of Mathematics. Similarly, it occurs in the aspect of multiplication before the use of the teaching aid of Napier bones. The multiplication is taught by stacking multiplication without any media or teaching aids. In fact, the criterion of minimum completeness (KKM) in MI Ma'arif Dukuh for Mathematics is 65.

In the implementation of cycle $\mathrm{I}$, the teaching material on multiplication has used the teaching aid of Napier bones. Beforehand, the researcher conducts pre-test to predict students' performance. The pre-test of cycle I shows that 21 students have achieved 62.38. It means that their scores remain below the criteria of minimum completeness (KKM). Further, the teaching occupies the use of teaching aid of Napier bones. At the end of class, the post-test is given, and the result displays their average scores at 70.23 with 12 student reach (57.14\%) at KKM. Based on the data of cycle I, the teaching and learning of Mathematics multiplication materials by using the teaching aid of Napier bones can improve students' learning outcome. Nevertheless, the number of students that reach KKM has not met the target. 


\section{Mudarrisa: Jurnal Kajian Pendidikan Islam, Vol. 10, No. 2, 2018}

In the cycle I, the use of teaching aid of Napier bones has escalated students' enthusiasm in learning the materials. The small group discussion makes them more unified, learn how to work together and reinforce their knowledge and understanding. At the beginning, the students still confuse how to solve the multiplication by using the teaching aid of Napier bones because some of them do not pay attention to the teacher explanation. Thus, the teacher firmly directs the students' focus to the tasks to avoid confusion and misunderstanding. In the question and answer session after teacher presentation, most students are active, and the rest are less active. Overall, all of them are enthusiastic during the process of learning.

Considering the reflection result from learning in cycle I, the data shows that the implementation of multiplication material by using the teaching aid of Napier bones in cycle I contains several supportive and resistant aspects. The supportive aspects are namely; 1) the majority of students are enthusiastic taking the learning activities, they seems to be interested to the teaching aid; 2) most students listen and pay attention to the teacher's explanation; 3) big number of students are able to answer the multiplication questions by using the media of Napier bones. Besides that, the researcher also find the resistant aspects in the implementation of learning of cycle I as follows; 1) the teacher has not given clear explanation on how to use Napier bones. To deal with that, in the cycle II the teacher has to give more details in presenting the procedure of the teaching aid of Napier bones; 2) some students find themselves difficult to compile the Napier bones because they have not memorised the number multiplication 
1-9. For the resolution, in the cycle II the teacher must provide reinforcement to the students by giving oral questions related to number multiplication $1-9$; 3) the teacher has not implemented teaching and learning based on lesson plan. Thus, in the cycle II, the teacher requires reading and understanding the lesson plan before conducting teaching and learning process.

On the basis of test result and reflection annotation in cycle I, the researcher proceeds the research into cycle II by implementing the teaching aid of Napier bones and improving the flaw and weaknesses in cycle I. In the cycle II, the researcher maximises the implementation of the teaching aid of Napier bones to students, and encounters several flaws occurred in cycle I. in this stage, the researcher also stimulates students' motivation to be more active and enthusiastic during teaching and learning process.

In the cycle II, the researcher remains occupying the typical teaching aid by improving the flaws and weaknesses in the implementation of cycle I. different from cycle I, the learning process in cycle II becomes more conducive, active, and passionate compared to that in cycle I. The less active students change into active ones and unified during the session of question and answer. The prominent management of condition and class environment promotes the smooth conduct of cycle II. The students that cannot focus and pay attention to the teacher recently have more focus and pay attention to the teacher during the process of learning. 
Cycle II carries on the multiplication materials by using the teaching aid of Napier bones. Before the cycle II implemented, the researcher conducts pre-test to 21 students that gain 73.09 average score. Respectively, the teaching and learning occur by using the teaching aid of Napier bones, and it ends with the post-test. The result of post-test reveals the average score of 79.05 . From such test, 18 students $(85.71 \%)$ have passed the KKM, and the rest (3 students or 14.28\%) requires reinforcement. Based on the observation, those three students have no achieved the target because of less motivation to study, less attention to follow the learning process, less active during the learning.

Based on criteria, the learning outcome has succeeded if it fulfils the ideal standard of $85 \%$ students meet KKM. As the result of cycle II, the implementation of the research has been satisfied because the result achieves the targeted standard. Thus, there is no need more cycle to implement. Overall, the use of teaching aid of Napier bones has improved the learning outcome of Mathematics on the aspect of multiplication for fourth grade students of MI Ma'arif Dukuh, Salatiga, on both cycle I and cycle II. At the end of the research, 18 students (85.71\%) have finally met the learning completeness.

\section{CONCLUSION}

This research concludes that the use of Napier bones can improve learning achievement of Mathematics on the aspect of multiplication for fourth grade students of MI Ma'arif Dukuh Sidomukti Salatiga in the academic 
year $2016 / 2017$. The fact can be overviewed from the majority number of students that achieve the targeted score of minimum completeness including 18 students or $85,71 \%$. The big number of students have risen over the standard of learning completeness i.e. $85 \%$ from the total population.

\section{REFERENCES}

Adina, A., \& Colomeischi, T. (2015). The Students `Emotional Life and Their Attitude toward Mathematics Learning. Procedia - Social and Behavioral Sciences, 180(November 2014), 744-750.

Anam, Fatkhul, Pretty, \& Suryono. (2009). Matematika 4. Jakarta: Pusat Perbukuan Departemen Pendidikan Nasional.

Arikunto, S., et. al. (2015). Penelitian Tindakan Kelas. Jakarta: PT Bumi Aksara.

Arsyad, A. (2009). Media Pembelajaran. Jakarta : Rajawali Pers.

Asmani, J. M. (2011). Tips Pintar PTK: Penelitian Tindakan Kelas. Jogjakarta: Laksana.

Basleman, A. \& Mappa, S. (2011). Teori Belajar Orang Dewasa. Bandung: PT Remaja Rosdakarya.

Daryanto. (2011). Penelitian Tindakan Kelas dan Penelitian Tindakan Sekolah.Yogyakarta: Gava Media.

Daryanto. (2012). Model Pembelajaran Inovatif. Yogyakarta: Gava Media.

Daryanto. (2013). Inovasi Pembelajaran Efektif. Bandung : Yrama Widya

Djamarah, S. B. (2000). Guru dan Anak Didik dalam Interaksi Edukasi. Jakarta: Rineka Cipta

Fathoni, A. (2011). Metodologi Penelitian E Teknik Penyusunan Skripsi. Jakarta: Rineka Cipta.

Hamdani. (2011). Strategi Belajar Mengajar. Bandung : pustaka Setia.

Jihad, A. \& Haris, A. (2013). Evaluasi Pembelajaran. Yogyakarta: Multi Pressindo.

Kastolani. (2014). Pembelajaran Inovatif : Teori dan Aplikasi. Salatiga: STAIN Salatiga Press. 
Ningsih, A. (2015). Pengaruh Penggunaan Media Batang Cuisenaire terhadap Hasil Belajar Siswa pada Materi Penjumlahan Dan Pengurangan Bilangan Di Sekolah Dasar. Jurnal Penelitian Pendidikan Guru Sekolah Dasar, 03(02), 1912-1921.

Rambousek, V., Štípek, J., \& Vaňková, P. (2016). Contents of Digital Literacy from the Perspective of Teachers and Pupils. Procedia Social and Behavioral Sciences, 217, 354-362.

Sriyanti, L., et. al. (2009). Teori-Teori Belajar. Salatiga: STAIN Salatiga Press.

Sugiyarti, S., et. al. (2009). Matematika untuk SD/MI Kelas 4. Jakarta: Pusat Perbukuan, Departemen Pendidikan nasional

Sundayana, R. (2015). Media dan Alat Peraga dalam Pembelajaran Matematika. Bandung: Alfabeta.

Suprijono, A. (2011). Cooperative Learning Teori dan Aplikasi PAIKEM. Yogyakarta: Pustaka Belajar.

Susanto, A. (2013). Teori Belajar dan Pembelajaran di Sekolah Dasar. Jakarta: Kencana Prenada Media Group.

Suwardi, Anitah, W. S., Akhyar, M. \& Asrowi. (2017). Gender Bias in Islamic Textbooks for Muslim Children in Indonesia. Attarbiyah: Journal of Islamic Culture and Education. 2 (2). 214-235.

Suwardi, Anitah, W. S., Akhyar, M. \& Asrowi. (2017). The Relevance Of Pictures As Media In Thematic Learning Book With Pluralism Values In Indonesia. International Journal of Law, Government and Communication (IJLGC). 2 (6). 01-08.

Suyadi. (2011). Panduan Penelitian Tindakan Kelas. Jogjakarta: DIVA Press.

Trianto. (2007). Model Pembelajaran Terpadu dalam Teori dan Praktek. Jakarta: Prestasi Pustaka.

Wardoyo, S. M. (2013). Penelitian Tindakan Kelas. Yogyakarta: Graha Ilmu.

Yonny, A., et. al. (2012). Menyusun Penelitian Tindakan Kelas. Yogyakarta: Familia.

Kusumah, Y. S. (March 18, 2017). Asyiknya Melakukan Perkalian dengan Tulang Napier. http://www.gurupintar.ut.ac.id/index.php/80-labpendidikan/seri-embelajaran-sd/152-asyiknya-melakukan-perkaliandengan-tulang-napier

Sumardyono. (Oct 15, 2016). Karakteristik Matematika dan Implikasinya 
Mudarrisa: Jurnal Kajian Pendidikan Islam, Vol. 10, No. 2, 2018

terhadap Pembelajaran Matematika. Paket Pembinaan Penataran (online), (http://www.p4tkmatematika.org). 